\title{
APLIKASI ALGORITMA GENETIKA DALAM MENENTUKAN SPESIFIKASI PC BERDASARKAN KEMAMPUAN FINANSIAL KONSUMEN
}

\author{
Eva Haryanty, S.Kom. ${ }^{*}$
}

\begin{abstract}
ABSTRAK
Komputer adalah salah satu peralatan yang pada saat ini banyak pula digunakan baik oleh individu maupun isntitusi. Dipergunakannya komputer tetntunya tak lepas dari upaya manusia untuk membantu menyelesaikan permasalahan yang ditemui agar dapat dengan cepat diselesaikan. Banyak aplikasi yang telah dibuat untuk mendukung pekerjaan dalam bidang-bidang tertentu, salah satunya adalah aplikasi dengan metode algoritma genetika.

Hasil penelitian ini adalah sistem dapat melakukan pencarian dengan menggunakan metode algoritma genetika untuk mendapatkan solusi yang optimal dengan output berupa spesifikasi PC, dimana total harga yang didapat mendekati dengan kemampuan finansial yang telah di-inputkan oleh konsumen.
\end{abstract}

Kata Kunci: Algoritma Genetika

\section{PENDAHULUAN}

Komputer adalah salah satu peralatan yang pada saat ini banyak pula digunakan baik oleh individu maupun isntitusi. Dipergunakannya komputer tetntunya tak lepas dari upaya manusia untuk membantu menyelesaikan permasalahan yang ditemui agar dapat dengan cepat diselesaikan. Banyak aplikasi yang telah dibuat untuk mendukung pekerjaan dalam bidang-bidang tertentu, salah satunya adalah aplikasi dengan metode algoritma genetika.

\subsection{Latar Belakang}

Seiring dengan berkembangnya ilmu pengetahuan dan teknologi yang begitu pesat belakangan ini muncul masalah-msalah baru, antara lain adalah masalah optimasi. Optimasi adalah pencarian nilai-nilai variabel yang dianggap optimal, efektif dan juga efisien untuk mencapai hasil yang diinginkan. Masalah optimasi ini beraneka ragam tergantung dari bidangnya, misalnya dalam industri antara lain pengaturan jam kerja karyawan, jumlah persediaan bahan baku, jalur distribusi yang optimal dan sebagainya.

Dalam penelitian ini, masalah optimasi yang dipilih adalah masalah dalam bidang komputer, dimana akan dicari optimasi dalam pencarian spesifikasi komputer yang disesuaikan dengan kemampuan finansial konsumen.

Untuk itu diperlukan suatu metode untuk mendapatkan nilai-nilai variabel yang optimal dari perumusan masalah tersebut. Bermula dari tuntutan masalah optimasi tersebut, pada tahun 70-an muncul sebuah algoritma baru yang dikenal dengan algoritma genetika yang berfungi untuk memberikan solusi untuk masalah optimasi.

\footnotetext{
* Staf Pengajar Program Studi S1-Teknik Informatika IKADO
} 


\subsection{Perumusan Masalah}

Dari latar belakang yang ada, maka permasalahan yang ada adalah bagaimana membuat suatu sistem kecerdasan buatan dalam bidang komputer untuk pemilihan spesifikasi komputer dengan menggunakan metode algoritma genetika untuk menentukan spesifikasi PC berdasarkan kemampuan finansial konsumen.

\section{TINJAUAN PUSTAKA}

Ide dasar algoritma genetika dalam pencarian solusi adalah emulasi apa yang terjadi dalam evolusi genetika populasi makhluk hidup untuk bertahan dalam memnghadapai seleksi alam.

\subsection{Pengertian}

Algoritma Genetika diciptakan berdasarkan inspirasi dari mekanisme seleksi alam dimana individu yang lebih kuat menjadi pemenang dari lingkungan yang berkompeisi. Konsep dasar Algoritma Genetika relatif mudah dipahami, karena komponen-komponen pembentuk algoritma ini mencerminkan kehidupan di alam, seperti contohnya mekanisme seleksi, pindah silang, mutasi, dan lain-lain.

Proses pemilihan biasanya dilakukan secara acak, stirng dengan kualitas yang lebih baik akan memiliki peluang lebih besar untuk terpilih sebagai calon string generasi berikutnya. Proses rekombinasi meliputi proses genetika untuk memperoleh string baru dari pertukaran karakter dari calon string yang didapat pada tahap seleksi. String pada generasi baru dihasilkan dengan menggunakan operasi genetika secara acak pada calon string yang terpilih pada tahap seleksi. Proses rekombinasi akan menghasilkan string baru yang berbeda dibandingkan induknya dan dengan demikian diperoleh domain pencarian yang baru.

\subsection{Siklus Algoritma Genetika}

Cara kerja dari algoritma genetika seherhana, hanya mencakup proses penduplikasian string dan pertukaran bagian dari string. Meskipun cukup sederhana, tetapi mempunyai kemampuan menyelesaikan persoalan optimasi. Kemampuan ini didukung oleh 3 operator genetik, yaitu reproduksi, pindah silang dan mutasi.

Pada reproduksi terjasi proses penduplikasian string berdasarkan nilai fungsi obyektifnya. Nilai obyektif ini dapat dilihat sebagai suatu keuntungan yang ingin dicapai atau dimaksimalkan. Sementara proses pertukaran bagian string dilakukan oleh operator pindah silan dan mutasi. Di samping ketiga operator dasar, parameter genetik serta sumsi yang digunakan dalam pemodelannya juga mempunyai peran penting.

\subsection{Jenis dan Sususan Kromosom}

Berdasarkan jenis dan susunan kromosom maka algoritma genetika dapat dibedakan menjadi 4 macam.

\subsubsection{Kromosom Float}

Dalam algoritma genetika, susunan kromoson dibentuk dengan menggunakan nilai float untuk setiap gennya, sehingga berbentuk dari sekempulan nilai float. 


\subsubsection{Kromosom Biner}

Dalam algoritma genetika, susunan kromosom dibentuk dengan menggunakan nilai biner unutk setiap gennya Algoritma genetika jenis ini merupakan model representasi yang paling dekat dengan model alamiahnya.

\subsubsection{Kromosom String}

Susunan kromosom dibentuk dengan menggunakan nilai string untuk setiap gennya. Nilai ini bisa berupa angka, huruf atau karakter lainnya. Model ini mirip dengan algoritma genetika dengan kromosom biner, hanya saja represetasi gennta berbeda.

\subsubsection{Kromosom Kombinatorial}

Susunan kromosomnya dibentuk dengan menggunakan nilai kombinasi atau string, kromosomnya tidak hanya berbentuk kumpulan string tetapi juga memperhitungkan urutan atau posisi gen untuk setiap kromosomnya.

\section{ANALISA DAN DESAIN SISTEM}

Pada bab ini akan diuraikan deskripsi serta analisa sistem sebagai bentuk nyata implementasi algoritma genetika ke dalam aplikasi.

\subsection{Deskripsi dan Analisa Sistem}

Pada dasarnya sistem ini merupakan sistem pencarian seperti sistem pencarian yang lain, hanya saja metode yang digunakan adalah metode algoritma genetika. Suatu algoritma yang menggunakan pendekatan teori evolusi, diaman individu yang terkuatlah yang mampu bertahan dan melajutkan kehidupan.

Dengan pendekatan tersebut sistem akan memulai mencari solusi secara acak yang didapat dari setiap kemungkinan yang ada. Setiap solusi yang didapat akan dievaluasi dan diuji nilai kelayakannya, dilakukan proses regenerasi sampai beberap generasi, sehingga didapat solusi yang terkuat yang mampu bertahan yang akan menjadi solusi pilihan.

\subsubsection{Definisi Individu}

Individu menyatakan urutan komponen PC yang dinyatakan dalam nilai integer sebanyak 5 gen yang merupakan nomor unit komponen PC dalam database pada tiap kategori yang terdiri dari :

- 1 bit gen yang menyatakan jenis processor.

- 1 bit gen yang menyatakan jenis mainhoard.

- 1 bit gen yang menyatakan jenis memori.

- 1 bit gen yang menyatakan jenis vga card.

- 1 bit gen yang menyatakan jenis harddisk.

\subsubsection{Fungsi fitness}

Dalam aplikasi ini dicari total harga yang paling mendekati dengan nilai kemampuan finansila konsumen, sehingga fungsi fitness dinyatakan sebagai invers dari nilai absolut jumlah total harga komponen dikurangi dengan nilai kemampuan finansial konsumen. 


\subsubsection{Populasi Awal, Proses Seleksi, Cross Over dan Mutasi}

Untuk membentuk populasi awal, maka perlu dibangkitkan sejumlah individu, dalam aplikasi ini satu populasi terdiri dari 8 individu yang merupakan urutan komponen PC, sehingga dibangkitkan 8 individu dengan 5 gen yang dibangkitkan secara acak.

Sistem pertama kali akan mengambil 1 nilai acak yang merupakan nomor urut komponen prosesor. Kemudian sistem akan menghitung jumlah komponen mainhoard yang sesuai untuk jenis prosesor terpilih. Dari jumlah yang didapat akan dijadikan dasar untuk mengambil 1 nilai acak. Dari kumpulan komponen mainhoard yang didapat yang terkumpul dalam satu recordset, akan diambil satu beradasarkan nilai acak yang didapat.

Penentuan jenis memori juga didasarkan pada jenis mainhoard terpilih. Kembali sistem akan menghitung jumlah komponen meori yang sesuai dengan jenis mainhoard terpilih. Dari jumlah yang didapat yang dijadikan dasar untuk mengambil 1 nilai acak. Dari kumpulan komponen memori yang didapat yang dikumpulkan dalam 1 recordset, akan diambil 1 berdasarkan nilai acak yang didapat.

Setelah terbentuk populasi awal, maka sistem akan menghitung total harga tiap individu pada populasi dengan cara mengambil record harga untuk setiap komponen. Setelah total harga didapat maka dihitung dengan menggunakan fungsi fitness seperti telah dijelaskan di atas.

Pembuatan roulette wheel dilakukan dengan cara menghitung jumlah total nilai fitness pada populasi. Besar bagian tiap individu tergantung dari besar prosentase nilai fitness tiap individu yang dihitung dari nilai fitness individu dibagi jumlah total fitness pada populasi dikalikan $100 \%$.

Crossover dilakukan dengan menukarkan gen 2 buah induk secara langsung, dengan metode one-point, dimana sistem akan menentukan 2 posisi gen awal pada induk yang akan dilakukan proses crossover.

Operator Mutasi melakukan operasi pembalikan atau perubahan secara permanen allele dari sebuah gen dalan kromosom sehingga karakteristiknya berubah. Dengan kata lain mutasi dilakukan dengan cara mengganti posisi gen yang dimutasi. Sistem ini akan menentukan 1 posisi yang diambil secara acak dan akan melakukan penggantian gen pada posisi tersebut dengan gen baru.

Anak hasil perkawinan silang dan mutasi menjadi generasi baru untuk dilakukan proses regenerasi. Pada generasi berikutnya, individu terbaik dapat dipertahankan dengan proses elitism.

Pada skema flowchart algoritma genetika, menggunakan beberapa parameter sebagai berikut :

- Kemampuan Finansial, yang nantinya dijadikan dasar untuk menghitung nilai fitness.

- Probabilitas fitness, yang nantinya dijadikan dasar untuk melakukan proses fitness.

- Probabilitas mutasi, yang nantinya dijadikan dasar untuk melakukan proses mutasi.

- Generasi, yang nantinya dijadikan dasaar sistem dalam melakukan pencarian hingga generasi tertentu.

Adapun cara kerja sistem ini adalah pertama dengan memasukkan parameter nominal uang, probabilitas fitness, probabilitas mutasi dan jumlah generasi. Kemudian dilanjutkan dengan membangkitkan populasi awal, selanjutnya terjadi proses evaluasi nilai, apabila proses evaluasi nilai memenuhi maka individu terbaik akan masuk pada 
proses generasi berikutnya. Namun apabila evaluasi nilai suatu individu tidak memenuhi nilai minimasi maka individu tersebut akan melewati proses seleksi, fitness, mutasi dan elitism sampai didapatkan nilai minimasi yang ditetapkan.

\section{KESIMPULAN DAN SARAN}

Kesimpulan yang diperoleh dari hasil penelitian sistem kecerdasan buatan menggunakan metode algoritma genetika untuk masalah yang dihadapi konsumen dalam menentukan spesifikasi PC adalah :

a. Sistem dapat melakuakn pencarian dengan menggunakan metode algoritma genetika untuk mendapatkan solusi yang optimal dengan output berupa spesifikasi PC, diaman total harga yang didapat mendekati dengan kemampuan finansial yang telah diinputkan konsumen.

b. Perubahan parameter seperti nilai propabilitas crossover dan mutasi serta jumlah generasi akan mempengaruhi hasil yang akan didapatkan.

c. Dalam melakukan pencarian dengan metode ini, sistem memerlukan waktu yang cepat.

Untuk saran, sistem ini masih memerlukan pengembangan lebih lanjut, karena pada sistem ini hanya akan menampilakn informasi bagi konsumen berupa spesifikasi PC yang terdiri dari beberapa komponen dasar saja. SIstem ini dapat dikembangkan lebih jaun dengan menambahkan berbagai komponen pendukung lainnya seperti cdrom, floppy disk, mouse dan keyboard.

\section{DAFTAR PUSTAKA}

Hermawanto, Denny, Algoritma Generika dan Contoh Aplikasinya, Surabaya. Lawrence, Davis, Handbook of Genetic Algorithms, New York : van Nostrand, 1991 Fathansyah, Ir, Basis Data, Bandung, 1999

Mitchell, Melanie, An Introduction To Genetic ALgorithm, Massachusetts, 1996 